\title{
Reactivation of Tuberculosis during Dual Therapy with Pegylated Interferon and Ribavirin for Chronic Hepatitis C about a Case
}

\author{
D. Soro*, S. Koné, A. Ouattara, A. W. Ndjitoyap, A. J. B. Okon, D. Diallo, C. Assi, K. E. Allah, \\ M. J. Lohoues Kouacou, B. M. Camara \\ Service d'Hépato-Gastroentérologie, CHU Cocody, Abidjan, Côte d'Ivoire \\ Email: ${ }^{*}$ drambake@yahoo.fr
}

Received 20 November 2014; accepted 12 July 2015; published 15 July 2015

Copyright (C) 2015 by authors and Scientific Research Publishing Inc.

This work is licensed under the Creative Commons Attribution International License (CC BY).

http://creativecommons.org/licenses/by/4.0/

$$
\text { (c) (i) Open Access }
$$

\begin{abstract}
The infection by the virus of the hepatitis $\mathrm{C}$ can be associated with other infectious diseases, including the viral and bacterial infections of which the tuberculosis. The infection to Mycobacterium tuberculosis can remain latent during several years and show itself during a state of immunesuppression. The role of the antiviral treatment in the reactivation of the tuberculosis is debated. We bring back an observation of tubercular reactivation during dual therapy with pegylated interferon and ribavirin for a viral chronic hepatitis $C$. A virologique answer slow was obtained in the 40th week, as well as the reactivation of the tuberculosis. The tuberculosis was of ganglionic localization at our patient. The antituberculous treatment was established while maintaining the treatment. The evolution of the tuberculosis under treatment was favorable but for the VHC, we noted a virologique answer with premature relapse.
\end{abstract}

\section{Keywords}

Chronic Hepatitis C Virus, Tuberculosis, Treatment

\section{Introduction}

Chronic infection with hepatitis $\mathrm{C}$ virus (HCV) can be associated with other infectious diseases whether viral infections (HIV and HBV), bacterial infections such as tuberculosis or sexually transmitted diseases [1]. The

*Corresponding author.

How to cite this paper: Soro, D., et al. (2015) Reactivation of Tuberculosis during Dual Therapy with Pegylated Interferon and Ribavirin for Chronic Hepatitis C about a Case. Open Journal of Gastroenterology, 5, 83-87.

http://dx.doi.org/10.4236/ojgas.2015.57014 
association of chronic hepatitis $C$ to tuberculosis has been described with a prevalence of $3.3 \%$. Tuberculosis infects about a third of the world population [2] can remain dormant for several years and be in a state of immunosuppression. Reactivation of tuberculosis induced antiviral therapy for chronic hepatitis $\mathrm{C}$ was reported in the literature but the link remains controversial. We report a case of tuberculosis reactivation occurred during antiviral therapy (pegylated interferon and ribavirin) for chronic hepatitis C.

\section{Case Report}

Miss NAB Ivorian 56 years old, with a history as a blood transfusion 10 years ago following a hysterectomy, carries a viral hepatitis $C$ chronic active, diagnosed in 2010, genotype $1 \mathrm{~b}$ with a high viral load of 7,441,824 $\mathrm{IU} / \mathrm{ml}$, strong cytolytic to 6.8 times the upper limit of normal (ULN) for ALAT, $3.6 \times$ ULN for ASAT and an estimated A3F4 by Actitest Fibrotest and histological activity. The patient was asymptomatic with a body mass index (BMI) $22 \mathrm{~kg} / \mathrm{m}^{2}$. The indication for treatment with combination therapy with pegylated interferon alpha $2 \mathrm{a}$ plus ribavirin was made. The clinical assessment including blood count, urea, glucose, creatinine, prothrombin time, the protidogramme, lipid and hormonal assessment were normal. The HIV serology and HBV were negative. The gamma-glutamyl transferase to 4 times normal and normal alpha-fetal protein. Upper gastrointestinal endoscopy, abdominal ultrasound and chest X-ray were normal. Treatment was established in November 2010 with pegylated interferon-2a $\left(\right.$ PEGASYS $^{\mathrm{R}}$ ) at a dose of $180 \mu \mathrm{g} /$ week subcutaneously plus ribavirin (COPEGUS ${ }^{\mathrm{R}}$ ) at a dose of $1000 \mathrm{mg} /$ day in two divided doses orally.

The response to treatment was marked by the persistence of biochemical activities (transaminases 2.5 times normal) associated with leukopenia $\left(3300 / \mathrm{mm}^{3}\right)$, neutropenia $\left(1216 / \mathrm{mm}^{3}\right)$, normochromic normocytic anemia $(9.3 \mathrm{~g} / \mathrm{dl})$ and thrombocytopenia $\left(106,000 / \mathrm{mm}^{3}\right)$. The patient received red blood cell growth factors based Recormon $^{\mathrm{R}} 30,000$ subcutaneously and slow viral response was achieved in 40 weeks.

At week 40, the patient presented with an extra firm and mobile right clavicular lymphadenopathy with signs of tuberculous impregnation. There was a marked absence of pulmonary signs and urinary ascites. Abdominal ultrasound (Figure 1) found deep abdominal lymph nodes, liver homogeneous regular contours and confirmed the absence of ascites.

The tuberculin skin test was phlyctenular. A chest radiograph was normal. The search for Mycobacterium tuberculosis was negative in the liquid sputum and urine. A lymph node biopsy was performed which pathological examination showed epithelioid granulomas with giant cell caseating confirming the diagnosis of lymph node tuberculosis (Figure 2). Antituberculosis quadruple therapy pyrazinamide (1800 mg/day), isoniazid (300 mg/day), rifampicin (600 mg/day) and ethambutol (1500 mg/day) was established for a period of two months followed by two drugs (isoniazid $300 \mathrm{mg}+$ rifampicin $600 \mathrm{mg}$ ) for four months. The total duration of tuberculous treatment was six months. With treatment, the outcome was marked by the disappearance of lymphadenopathy and signs of tuberculous impregnation. Antiviral treatment was continued until the 96th week still undetectable viremia. Stock control six months after cessation of antiviral therapy was marked by early relapse with viremia to 273 $\mathrm{IU} / \mathrm{ml}(2.44 \log )$.

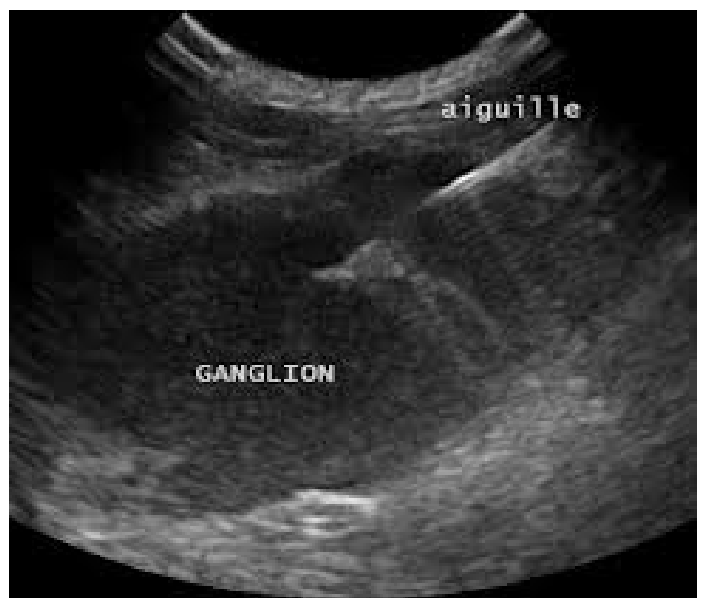

Figure1. Ultrasound image of a deep abdominal lymphadenopathy. 


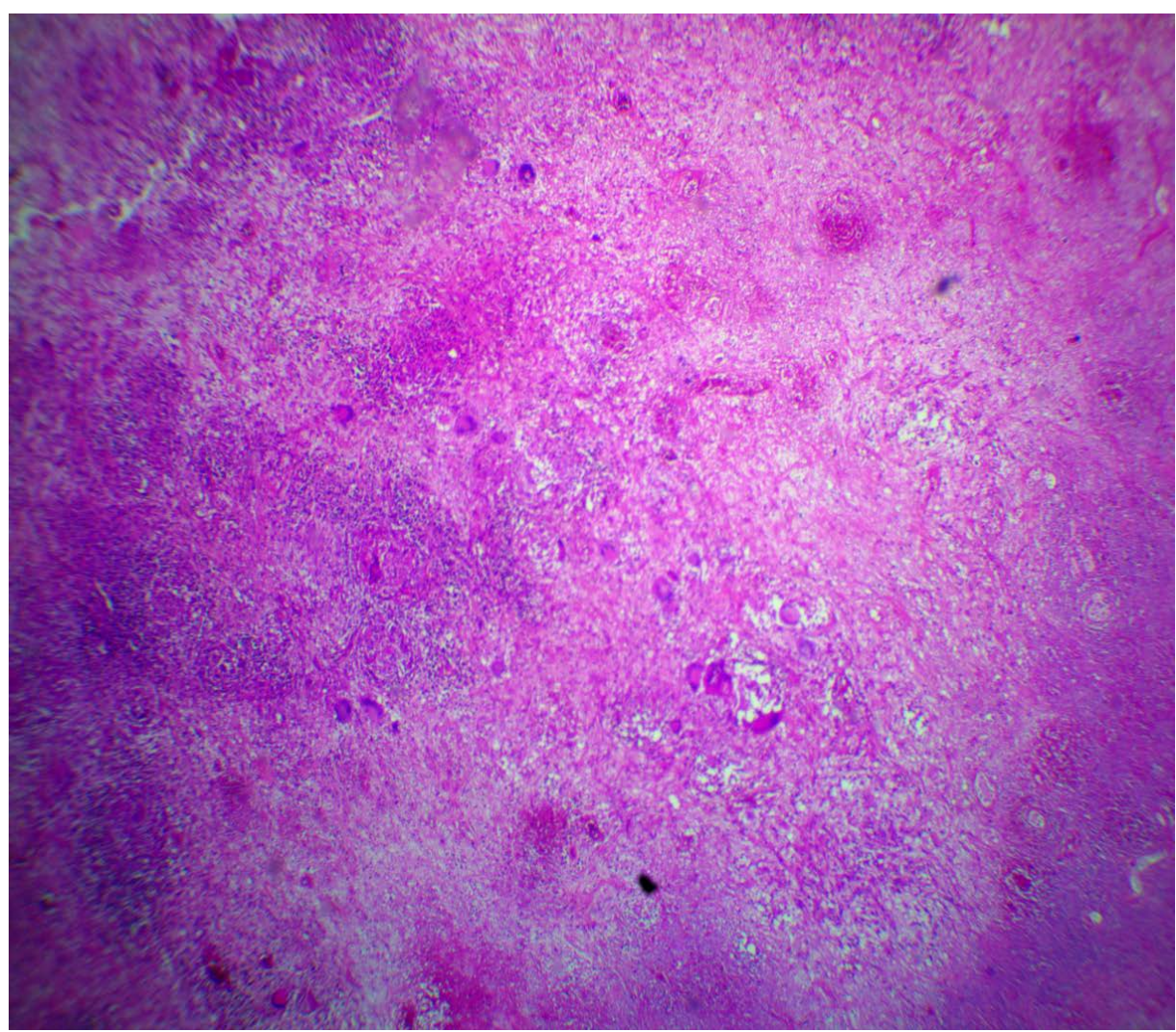

Figure $2 . \mathrm{HE} \times 100$ granulomatous reaction made of epithelioid cells, Langhans-type giant cells and a lymphocytic crown centered caseous necrosis.

\section{Discussion}

Infection with the hepatitis C virus (HCV) may predispose them to other infectious diseases, viral or bacterial. Thus, a multicenter case-control study showed a higher incidence of infections in patients infected with HCV compared to controls (3.3\% versus $1.3 \%$ for tuberculosis) [1]. Impairment secondary to infection with this virus immune mechanism has been suggested. Indeed, HCV appears to be able to replicate within mononuclear peripheral blood cells, thus compromising their antimicrobial activity [3]. In the Ozyilkan et al study, it was noted a reduction in the number of CD4 + T lymphocytes and CD4/CD8 ratio in patients with HCV positive serology [4]. The reasons for the occurrence of tuberculosis in immunocompetent patients and HCV remain unclear. It has recently been demonstrated that HCV-stimulated endogenous interferon $\alpha$. This active in CD4 T cells, the gene for interferon-gamma involved in the control of mycobacterial infections [5]-[7]. Reactivation of tuberculosis during antiviral therapy for chronic hepatitis C is exceptional. Only four cases have been previously reported in the literature known. The first observation was published in 2006 by Sabbatani et al. [8]. He was a 62 year old patient treated for chronic hepatitis $C$ with pegylated interferon and ribavirin and who experienced severe pulmonary tuberculosis in the seventh month of treatment. Antiviral treatment was maintained and the tuberculosis treatment has a favorable development [8]. The second case was reported by Farah et al. in 2007 [9] this was a patient treated for chronic hepatitis $\mathrm{C}$ combination therapy with standard interferon and ribavirin, complicated by pulmonary tuberculosis [9]. The last two cases were reported by Belkahla [10] this was urinary tuberculosis in a patient with lymph node and another.

We report a case of tuberculosis reactivation antiviral therapy (pegylated interferon and ribavirin) for chronic hepatitis C; it was lymph node tuberculosis. Virologic response was slow in our patient, who required 96 weeks of combination therapy, triple therapy is not available at this time in our resource-limited unlike the two cases reported by Belkahla or rapid virologic response [10]. The evolution of tuberculosis was favorable anti tuberculosis quadruple [11] as in other observations reported [8]-[10]. In our case, there was an early relapse 6 months after discontinuation of combination therapy. 
Several hypotheses to explain the reactivation of tuberculosis by antiviral therapy have been advanced. Eradication of the virus by treatment could affect mycobacterial infection through a cessation of stimulation of endogenous interferon- $\alpha$. The coincidence of tuberculosis reactivation with the negativity of viremia in our patient supports this hypothesis. Furthermore, interferon could occur through iatrogenic immunosuppression by inducing buffy neutropenia [12], as in our case. Finally, antiviral treatment may be decreasing the number and altering the function of CD4 + T cells [13].

Conversely, a possible protective role of interferon- $\alpha$ against Mycobacterium tuberculosis was reported. This was a patient with pulmonary tuberculosis aggravated by stopping interferon- $\alpha$, prescribed for chronic hepatitis C [14].

\section{Conclusion}

Reactivation of tuberculosis by the antiviral treatment of chronic hepatitis $\mathrm{C}$ is possible, although exceptional. It appears from the reported cases in the literature and our observation that tuberculosis can be pulmonary or extra pulmonary seat. Antiviral treatment can be maintained in combination with TB treatment. Screening for TB in highly endemic countries, in subjects with a history of tuberculosis or a concept of contagion could prevent reactivation in patient candidates for antiviral therapy.

\section{References}

[1] El-Serag, H.B., Anand, B., Richardson, P. and Rabeneck, L. (2003) Association between Hepatitis C Infection and Other Infectious Diseases: A Case for Targeted Screening? American Journal of Gastroenterology, 1, 167-174. http://dx.doi.org/10.1111/j.1572-0241.2003.07176.x

[2] Sudre, P., Ten Dam, G. and Kochi, A. (1992) La tuberculose aujourd'hui dans le monde. Bulletin de l'Organisation mondiale de la Santé, 70, 297-308.

[3] Zignego, A.L., De Carli, M., Monti, M., Careccia, G., La Villa, G., Giannini, C., et al. (1995) Hepatitis C Virus Infection of Mononuclear Cells from Peripheral Blood and Liver Infiltrates in Chronically Infected Patients. Journal of Medical Virology, 47, 58-64. http://dx.doi.org/10.1002/jmv.1890470112

[4] Ozyilkan, E., Tatar, G., Hacibertasoglu, A., Kayhan, A. and Telatar, H. (1993) Analysis of T-Helper and T-Suppressor Lymphocyte Subsets in Patients with Chronic Hepatitis C Virus Infection. Journal of Internal Medicine, 234, 436-437. http://dx.doi.org/10.1111/j.1365-2796.1993.tb00773.x

[5] Appelberg, R. (1994) Protective Role of Interferon Gamma, Tumor Necrosis Factor Alpha and Interleukin-6 in Mycobacterium tuberculosis and Mycobacterium avium Infections. Immunobiology, 191, 520-525. http://dx.doi.org/10.1016/S0171-2985(11)80458-4

[6] Brinkmann, V., Geiger, T., Alkan, S. and Heusser, C.H. (1993) Interferon Alpha Increase the Frequency of Interferon Gamma-Producing Human CD4 T Cells. The Journal of Experimental Medicine, 178, 1655-1663. http://dx.doi.org/10.1084/jem.178.5.1655

[7] MacQuillan, G.C., Mamotte, C., Reed, W.D., Jeffrey, G.P. and Allan, J.E. (2003) Up Regulation of Endogenous Intrahepatic Interferon Stimulated Genes during Chronic Hepatitis C Virus Infection. Journal of Medical Virology, 70, 219-227. http://dx.doi.org/10.1002/jmv.10381

[8] Sabbatani, S., Manfred, R., Marinacci, G., Pavoni, M., Cristoni, L. and Chiodo, F. (2005) Reactivation of Severe Acute Pulmonary Tuberculosis during Treatment with Pegylated Interferon-Alpha and Ribavirin for Chronic HCV Hepatitis. Scandinavian Journal of Infectious Diseases, 38, 205-208. http://dx.doi.org/10.1080/00365540500263268

[9] Farah, R. and Award, J. (2007) The Association of Interferon with the Development of Pulmonary Tuberculosis. International Journal of Clinical Pharmacology and Therapeutics, 45, 598-600. http://dx.doi.org/10.5414/CPP45598

[10] Belkahla, N., Kchir, H., Maamouri, N., Ouerghi, H., Hariz, F.B., Chouaib, S., Chaabouni, H. and Mami, N.B. (2010) Réactivation d'une tuberculose sous bithérapie interféron-pégylé et ribavirine pour une hépatite chronique C. La Revue de Médecine Interne, 31, e1-e3. http://dx.doi.org/10.1016/j.revmed.2009.11.017

[11] Van Voccen, J.P. (2010) Diagnostic et traitement de la tuberculose, manuel pratique, recommandations destinées au corps médical. FARES asbl.

[12] Fried, M.W. (2002) Side-Effects of Therapy of Hepatitis C and Their Management. Hepatology, 36, S237-S244. http://dx.doi.org/10.1002/hep.1840360730

[13] Scanga, C.A., Mohan, V.P., Yu, K., Joseph, H., Tanaka, H., Chan, J., et al. (2000) Depletion of CD4+ T-Cells Causes Reactivation of Murine Persistant Tuberculosis Despite Continued Expression of Interferon Gamma and Nitric Oxide 
Synthetase 2. The Journal of Experimental Medicine, 192, 347-358. http://dx.doi.org/10.1084/jem.192.3.347

[14] Nahon, P., Brugière, O., Marcellin, P. and Valla, D. (2004) Rôle protecteur accidentel de l'interféron alpha contre Mycobacterium tuberculosis au cours d'un traitement anti viral C. Gastroentérologie Clinique et Biologique, 28, 609-618. http://dx.doi.org/10.1016/S0399-8320(04)95020-8 